Review

\title{
SEA BUCKTHORN VEGETATIVE PARTS - A GOOD SOURCE OF BIOACTIVE COMPOUNDS
}

\author{
Elga Šnē", Ruta Galoburda**, and Dalija Segliṇa* \\ * Latvia State Institute of Fruit Growing, Graudu iela 1, Dobele, LV-3701, LATVIA \\ elga.sne@gmail.com \\ ** Latvia University of Agriculture, Lielā iela 2, Jelgava, LV-3001, LATVIA
}

Contributed by Dalija Seglina

\begin{abstract}
In recent years, due to the health problems and better life expectancy, natural sources of bioactive substances have gained wide interest. Sea buckthorn is well known as a valuable plant and is widely used in traditional medicine for the treatment of diseases and disorders. A considerable amount of literature has been published on sea buckthorn berries, although all parts of sea buckthorn plant are considered as a source of a large amount of biological active substances, and believed to have beneficial health effects. Therefore, vegetative parts would be a good raw material not only for medicinal, cosmetic and pharmaceutical properties, but also for the food industry. This has increased the research on different sea buckthorn vegetative parts and their extract activity and toxicity. Sea buckthorn leaves have attracted interest during the past few years as the most promising source of active compounds after berries. They contain a wide range of hydrophilic and lipophilic bioactive compounds, which exhibit remarkable anti-oxidant potential together with anti-bacterial, anti-viral, anti-tumour and anti-inflammatory activity. Therefore, extracts of the plant leaves could be used as natural replacements for synthetic additives and for food products with functional properties. This creates the need to investigate the biochemical content of sea buckthorn vegetative parts grown in Latvia.
\end{abstract}

Key words: Hippophae rhamnoides L., leaves, stems, shoots, bark, roots, chemical composition, extract activity and toxicity, food processing.

\section{INTRODUCTION}

Sea buckthorn (Hippophae rhamnoides L.) is a thorny deciduous plant widely grown in Eurasian countries (Jeong et al., 2012). Sea buckthorn is a diverse plant with many uses starting from a control of soil erosion to use as horse fodder, a food component, and also in tea, drugs and cosmetics (Maheshwari et al., 2011). Different parts of this plant are considered as a good source of bioactive substances and used in folk medicine (Guliyev et al., 2004; Kumar et al., 2011).

Consumption of fruits, vegetables and other plant-derived products is positively correlated with beneficial health effects on the human body (Kondakova et al., 2009; Michel et al., 2012), due to presence of biologically active substances such as phenols, tocopherols and carotenoids, vitamin C, etc. Therefore, there is a growing interest in medicinal plants, spices and other herbs (Prabhu et al., 2011).

Mainly berries of this plant have been studied and used in the food, pharmacy and cosmetic industries (Michel et al., 2012) while data on other sea buckthorn parts are insufficient, except leaves, which during last ten years have aroused great interest of scientists.
Extracts of sea buckthorn vegetative parts are reported to possess antioxidant and antibacterial activity, and therefore could be used also as food additives instead of synthetic ones, as dietary supplements, and also as ingredients in functional foods. Due to health problems and in order to maintain wholesome food, natural sources of bioactive substances in the food industry are demanded (Hossain et al., 2010; Perumalla and Hettiarachchy, 2011). For example, the worldwide sale of functional foods is planned to grow from $\$ 75$ billion in 2007 to $\$ 130$ billion by 2015 (Negi, 2012).

Already Shunguang et al. (2003) reported that sea buckthorn leaves and green tender branches (shoots) have a great potential development not only as forage additives and medicinal products, but also in food processing. They are a rich source of biologically active substances and have great productivity compared to berries.

Therefore, sea buckthorn vegetative parts have been studied in the Latvia State Institute of Fruit-Growing to determine chemical composition and activity of Latvia grown sea buckthorn plants, differences between plant parts, gender influence, and harvesting time effect. Such research is 
needed in order to develop new products or additives derived from sea buckthorn plant with biologically high value and activities.

A literature review is performed to summarise the information, experience and discussions regarding the aspects of this stock material that could be useful for further research.

\section{THE CHEMICAL COMPOSITION OF SEA BUCK- THORN VEGETATIVE PARTS}

All parts (leaves, stems, shoots, bark, roots, and berries) of sea buckthorn are considered as a good source of biologically active compounds ( $\mathrm{Zu}$ et al., 2006; Upadhyay et al., 2010; Lee et al., 2011) and concentrations vary according to the origin, climate, method of extraction (Saggu et al., 2007), harvesting time, and year of harvest. Nevertheless, sea buckthorn research and processing has been mainly focused on berries, but also seeds and their oil. The berries are well known for their nutritional value and therapeutic properties (Xu et al., 2011), due to remarkable amounts of vitamins, carotenoids, organic acids, and minerals (Lee et al., 2011; Maheshwari et al., 2011). Despite the well documented chemical composition of berries, there is a lack of information about vegetative parts of sea buckthorn.

According to various authors, different sea buckthorn parts contain vitamins, carotenoids, phenolics, organic acids, tocopherols, sterols, triterpenes, and some essential amino acids (Bekker and Glushenkova, 2006; Arimboor 2008; Chauhana et al., 2008; Saggu and Kumar, 2008).

Phenolics are one of the most studied plant secondary metabolites, due to their biological activity, which is believed to aid in health promotion and disease prevention (Kondakova et al., 2009). Phenolics such as flavonoids, phenolic acids, and tannins are considered as the major contributors to these biological properties (especially antioxidant activity) of sea buckthorn (Arimboor et al., 2008; Michel et al., 2012; Upadhyay et al., 2010).

Leaves together with flowers contain large amounts of flavonoids (Chauhana et al., 2008), of which four (flowers) to eight (leaves and berries) compounds have been detected (Bekker and Glushenkova, 2001). The major flavonoids in berries are quercetin, kaempherol and isorhamnetin and their glycosides, and in addition leaves contain also catechin, myricetin, and their glycosides are reported (Bekker and Glushenkova, 2001; Geetha et al., 2003; Arimboor et al., 2008; Zu et al., 2006; Kumar et al., 2008). Furthermore, similar to hawthorn, sea buckthorn leaves have higher flavonoid content than berries, especially when berries have stopped growth and after ripening (Hua and Zhang, 2008).

Of phenolic acids with high antioxidant activity in sea buckthorn leaves, gallic, caffeic, chlorogenic, cinnamic, sinapic, $p$-coumaric, $p$-hydroxybenzoic, protocatechuic, gentisic, syringic, ferulic, and ellagic acids has been found, while in roots- gallic and syringic acid (Bekker and
Glushenkova, 2001; Arimboor et al., 2008; Kalia et al., 2011).

Other phenolics reported in sea buckthorn leaves are catechins such as (-)-epicatechin, (+)-gallocatechin, (-)-epigallocatechin, (+)-gallocatecholgallate, (-)-epicatecholgallate, and (-)-gallocatechin, and proanthocyanidins, like procyanidin and prodelphinidin (Bekker and Glushekova, 2001), and coumarin, and the concentrations of these are higher in leaves than in berries (Hua and Zhang, 2008). (The classification names of compounds mentioned in Bekker and Glushenkova (2001) have been changed, at present these are not accurate and used anymore.) Michel et al. (2012) compared the phenol and condensed tannin (proanthocyanidin) concentrations of leaf, stem, root and seed extracts and their fractions using different solvents, and roots and seeds of sea buckthorn showed the best results.

Sea buckthorn leaves are reported to contain carbohydrates such as sucrose, glucose and fructose (Bekker and Glushenkova, 2001) and considerable amounts of proteins (Li and Wardle, 2003). Moreover, while leaves have been reported to contain 13 amino acids, woody parts (bark, suckers) contain even 17 (Bekker and Glushenkova, 2001).

According to Bekker and Glushenkova (2001), the concentrations of polyunsaturated acids like linoleic $(18: 2)$ and alpha-linolenic $(18: 3)$ in sea buckthorn leaves are comparable to those in sea buckthorn seeds. Smaller amounts are reported for oleic $(18: 1)$ and palmitic acid $(16: 0)$, followed by behenic (22:0), stearic (18:0), myristic (14:0), heneicosanoic $(21: 0)$, pentadecanoic $(15: 0)$, and palmitoleic $(16: 1)$ acid.

Leaves contain vitamin E and folic acid (Arimboor et al., 2008; Hua and Zhang, 2008; Xu et al., 2011). The concentration of vitamin $\mathrm{C}$ can reach a value similar or higher to that found in berries or freshly squeezed juice (Bekker and Glushenkova, 2001). Similarly as in sea buckthorn fruits, the maximum occurs at the beginning of August and then decreases. In smaller amounts, vitamin $\mathrm{C}$ also occurs in sea buckthorn flowers, while the highest concentrations are in roots, and the concentration in plants grown at high altitudes can be twice that in freshly squeezed juice.

Many authors have reported that sea buckthorn leaves contain carotenoids (Saggu un Kumar 2007; Arimboor 2008; Chauhana et al., 2008; Kalia et al., 2011; Xu et al., 2011) like $\alpha_{-}, \alpha_{-}$, and $\delta$ - carotene, and lycopene. According to Bekker and Glushenkova (2001), at the cellular level chloroplasts of the leaves and fruit pulp have a common origin, and therefore, the highest concentrations of carotenoids occur in leaves and fruit.

Leaves are a source of microelements like calcium, magnesium, and potassium (Arimboor et al., 2008; Hua and Zhang, 2008; Kalia et al., 2011; Xu et al., 2011). In the study of Popescu et al. (2010) where mineral concentrations in plant leaf, fruit and vegetable material were determined, the highest levels of sodium, manganese, iron, zinc, and also calcium were found in sea buckthorn leaves. 
Also isoprenoids, including free and esterified sterols (ergosterol, stigmasterol, lanosterol) and triterpenes are found in sea buckthorn vegetative parts (Saggu and Kumar 2007; Arimboor et al., 2008; Chauhana et al., 2008; Hua and Zhang, 2008; Kalia et al., 2011).

Sea buckthorn bark is widely used in folk medicine, but the scientific data on its biochemical content and biological activities is limited. According to Chauhana et al. (2008), sea buckthorn bark has high serotonin concentration, which is much greater than in other plants (Bekker and Glushenkova, 2001). Nevertheless, it is also found in stems, leaves and fruits of sea buckthorn (Bekker and Glushenkova, 2001), though in smaller amounts. Also procyanidins, elagitannins, coumarines, triterpenoids, and carotenoids are found in sea buckthorn bark (Goldberg et al., 2004; Chauhana et al., 2008).

Several authors have reported that sea buckthorn vegetative parts contain different bioactive substances, but still there is a lack of information about particular compounds and their specific amounts. More information is available on sea buckthorn leaves and their phenolic levels, although a significant part of the information is outdated.

While the concentrations of phenolics have been studied quite intensively, other bioactive substances have been forgotten, and both qualitative and quantitative research on sea buckthorn leaves, shoots, bark, stems, and root is needed.

As Eurasian (India, China, Mongolia, and Russia) cultures have used this plant for a quite long time in traditional medicine, the sea buckthorn plant also has been much studied. information about sea buckthorn grown in such latitudes mostly is not accessible due to the lack of publications in peer reviewed journals.

\section{THE ACTIVITY OF SEA BUCKHORN EXTRACTS}

The sea buckthorn plant has been used extensively in traditional medicine mainly in Tibet, Mongolia, China, and India for the treatment of flu, cough, skin and mucosal disorders, gastric ulcers, asthma, cardiovascular and lung diseases, colitis and enterocolitis, hepatoxicity and hypoglycaemia (Geetha et al., 2002; Guliyev et al., 2004; Upadhyay et al., 2010; Maheshwari et al., 2011). It is believed that these properties are observed due to antioxidant compounds present in these plants (Geetha et al., 2002).

The vegetative parts of sea buckthorn contain large amounts of hydrophilic and lipophilic antioxidants, such us polyphenols, carotenoids, tocopherols, chlorophyll, and vitamin C (Jain et al., 2008; Saggu and Kumar, 2008; Kumar et al., 2011). Therefore, a strong antioxidant activity is reported by several authors. Upadhyay et al. (2010) compared the antioxidant activity of leaf extracts by ferric reducing antioxidant power (FRAP), 2,2'-diphenyl-1-picrylhydrazyl (DPPH) and 2,2'-azino-bis (3-ethylbenzothiazoline-6sulfonic acid) diammonium salt (ABTS) scavenging activ- ity. The results showed that ethanol extracts possessed a significantly higher antioxidant power than water extracts.

Among buckthorn plant parts with regard to the antioxidant activity, root ethanol extracts have higher antioxidant activity (by DPPH and FRAP assays) than leaf and stem extracts (Michel et al., 2012).

Different parts of the plant have been reported to possess not only antioxidant activity, but also antiviral, antifungal, antibacterial, antiinflammatory, antitumour, and antiradiation activity (Arimboor et al., 2008; Michel et al., 2012).

Also heptaprotective, immunomodulatory, antiradiation, antivisceral obesity, adaptogenic, and cytoprotective properties of ethanol and water leaf extracts have been detected in vitro and in tests with animals (Ganju et al., 2005; Geetha et al., 2002; Upadhyay et al., 2010; Kumar et al., 2011; Lee et al., 2011; Maheshwari et al., 2011).

The heptaprotective activity together with antioxidant activity of phenolic rich fraction (gallic acid, myricetin, quercetin, kaempherol, and isorhamnetin) of sea buckthorn leaves against $\mathrm{CCl}_{4}$-induced oxidative damage in rats was studied by Maheshwari et al. (2011). In the study animals were orally treated with 25,50 and $75 \mathrm{mg} / \mathrm{kg}$ of body weight of a phenolic rich fraction. The results suggested that this fraction in all concentrations had significant antioxidant activity by preventing oxidative damage of major molecules and protecting the liver cells from $\mathrm{CCl}_{4}$-induced oxidative stress. Therefore, the phenolic rich fraction of sea buckthorn leaves has potential in processing and could be used as a natural antioxidant and food supplement.

Antioxidant activity of leaf ethanol extract was evaluated by Narayanan et al. (2005) in glial cells during hypoxic exposure, while another group was treated with vitamin $\mathrm{C}$. The leaf extract inhibited hypoxia-induced cytotoxicity, mitochondrial integrity, reactive oxygen species production and DNA damage, indicating higher antioxidant activity than vitamin C.

Besides providing protection against hypoxia-induced oxidative damage, sea buckthorn leaf extract also can protect animals from chromium-induced oxidative damage (Geetha et al., 2003). The authors studied different concentrations of sea buckthorn leaf ethanol extract $(50,100$ and $250 \mathrm{mg} / \mathrm{kg}$ of body weight) for antioxidant activity against chromiuminduced oxidative stress in rats. Leaf extracts concentrations of 100 and $250 \mathrm{mg} / \mathrm{kg}$ showed significant antioxidant activity.

Geetha et al. (2002) reported a significant cytoprotective activity of alcohol leaf and fruit extracts at a concentration of $0.5 \mathrm{mg} / \mathrm{ml}$ against sodium nitroprusside-induced cytotoxicity and free radical production in murine macrophages.

Leaf drugs, due to presence of flavonoids, are useful in wound healing after chemical burns and plain wounds (Ganju et al., 2005; Padwad et al., 2006). In a study of adjuvant-induced arthritis rat model, sea buckthorn leaf 
extract showed antiinflammatory activity, which suggested therefore that it could be used in arthritis therapy (Ganju et al., 2005). A similar conclusion was reported by Padwad et al. (2006), who studied lipopolysaccharide-induced inflammatory response in murine macrophages. In a study (Harshit et al., 2011) of in-vitro antibacterial activity of sea buckthorn leaf extract at different concentrations $(0.5 \%, 2 \%, 3 \%$, $4 \%$, and $5 \%$ ) against common skin and wound pathogens using 160 microbial isolates obtained from clinical skin and wound infection cases of different animal species, an inhibitory effect at 5\% concentration was at a level 50\% compared to that of control standard drugs.

Antibacterial and antifungal activity has been reported for water and ethanol extracts of sea buckthorn parts by several authors (Jeong et al., 2010; Michel et al., 2012; Upadhyay et al., 2010; Arora et al., 2012). These extracts proved to be efficient against gram positive (B. cereus, E. durans, E. faecalis, $S$. aureus), gram negative (A. hydrophila, $B$. subtilus, E. coli, $P$. aeruginosa, $P$. fluorescens, $P$. jadinii, $S$. enterica, S. typhimurium, $Y$. enterolitica) bacteria and yeast (C. albicans).

Saggu et al. (2007) examined the effects of sea buckthorn leaf aqueous extract on adaptogenic activity in rats using a cold $\left(5^{\circ} \mathrm{C}\right)$-hypoxia $(428 \mathrm{mmHg})$-restraint $(\mathrm{C}-\mathrm{H}-\mathrm{R})$ animal model. Rats were orally treated with leaf water extracts of doses from $3.125-200 \mathrm{mg} / \mathrm{kg}$ body weight $30 \mathrm{~min}$ prior to $\mathrm{C}-\mathrm{H}-\mathrm{R}$ exposure and compared with the control group treated with water $(0.5 \mathrm{ml})$. The results suggested that sea buckthorn leaf extract at a dose of $100 \mathrm{mg} / \mathrm{kg}$ body weight possessed significant adaptogenic and antistress activity, both in a single and five doses given $30 \mathrm{~min}$ before C-H-R exposure. Further, this activity was explained by antioxidative activity, maintained blood glucose levels, better utilisation of free fatty acids and improved cell membrane permeability (Saggu and Kumar, 2008).

Potential antivisceral obesity and antioxidant effects of sea buckthorn leaf tea by the regulation of lipid and antioxidant metabolism were found in high-fat-diet-induced obese mice by Lee et al. (2011), when mice were fed with powdered tea (1\% and $5 \%$ ) for six weeks. Tea-fed mice showed suppressed body weight gain and significantly reduced visceral fat, plasma levels of leptin, triglyceride and total cholesterol, and alanine aminotransferase activity compared with the control high-fat fed animals.

Sea buckthorn leaf extract showed significant anti-dengue activity, when evaluated in Dengue virus type- 2 infected blood-derived human macrophages. As macrophages are the primary target of Dengue virus infections, the extract has potential for the treatment of Dengue (Jain et al., 2008).

Ethanol extract of sea buckthorn bark has been reported to possess wound healing activity in acetic acid-induced gastric lesions in rat stomach (Xu et al., 2007). Goldberg et al. (2004) studied the influence of different plant extracts on metastatic processes of tumour development in infected mice. The authors reported that sea buckthorn bark extracts possess antitumour effect by changing the oxygen level in normal and tumour tissues, which causes spasm of tumour vessels and inflammatory changes in them resulting in repression of processes in tumour tissues. Also Chauhana et al. (2008) reported antitumour activity of sea buckthorn bark extracts. The bark and sprout extracts also in long-term administration showed improvement of the hormonal metabolic organism status in rats that suffered from stress (Chauhana et al., 2008).

The greatest part of the scientific literature about different activities of extracts have been studied using crude or partially separated fractions, which contain also other compounds that could react synergistically. Therefore, it is not possible to determine which compound was responsible for the possessed activity of extract. Therefore, further research on the specific activities, identification and characterisation of the specific biochemical compounds is needed.

\section{THE SAFETY EVALUATION OF SEA BUCKTHORN VEGETATIVE PARTS}

The positive health effects of sea buckthorn are explained by their remarkable antioxidant activity (Saggu et al., 2007), which is observed mainly due to presence of phenolic compounds and their derivatives. Despite well-explored and documented phenolic compounds and their biological activities, nevertheless, only a few of them are currently allowed as food antioxidants (Shahidi and Naczk, 2004).

Together with a lack of information on chemical composition, biological properties and interactions on human body of sea buckthorn vegetative parts, there are only a few reports on safety evaluation of extracts made from sea buckthorn vegetative parts. Till now mainly leaf water extracts have undergone safety and toxicity tests, as water is the best solvent for phenol extraction in order to pass all safety tests in the food industry (Dudonne, 2009). Although experiments with sea buckthorn vegetative parts are performed using also other solvents such as ethanol, methanol, hexane, acetone, and their mixtures with water, only ethanol is considered as a low toxic (Michel et al., 2012) and is reported as one of the best for the extraction of phenols (Escribano-Bailon and Santos-Buelga, 2003).

It has been shown that sea buckthorn leaf water extract has no in vitro toxicity for BHK-cells at 25, 20, 2100, 200 and $400 \mu \mathrm{g} / \mathrm{ml}$ concentrations or side effects after dermal application on rats at the concentration of $5 \mathrm{~g} / \mathrm{kg}$ body weight (Upadhyay and Gupta, 2010).

The acute and sub-acute toxicity of lyophilised sea buckthorn leaf water extracts in rats has been estimated by biochemical and hematological parameters (Saggu et al., 2007). The acute toxicity is the adverse effect of a substance from short-term exposure to relatively high amounts of this substance, usually 24 hours. The substance is considered as acute toxic, if adverse effects occur within 14 days of the administration. In the tests, the median lethal dose $\left(\mathrm{LD}_{50}\right)$ 
shows the amount of dose after which $50 \%$ of cases have ended lethally for the test individuals (Saggu et al., 2007). Rats were orally administered doses of $1,2,5$ and $10 \mathrm{~g} / \mathrm{kg}$ body weight, and none of the used doses showed an acute toxic within 24 hours nor after 14 days of treatment. The oral $\mathrm{LD}_{50}$ of the sea buckthorn leaf water extract in rats was $10 \mathrm{~g} / \mathrm{kg}$ body weight. Also, sub-acute toxicity was investigated in rats by treating them orally with a single dose (1 and $2 \mathrm{~g} / \mathrm{kg}$ body weight) of sea buckthorn leaf extract for 14 days. There were no changes in biochemical parameters in comparison to the control rats, while in hematological parameters, significant changes in rats administered a $2 \mathrm{~g} / \mathrm{kg}$ body weight dose appeared. Still, regarding to the parameters and detected toxicity levels, the authors considered sea buckthorn leaf water extract as a low toxic.

Sea buckthorn leaf water extract is also safe and non-toxic with regard to heavy metal content, as $\mathrm{As}, \mathrm{Pb}, \mathrm{Hg}, \mathrm{Cd}, \mathrm{Zn}$, $\mathrm{Cu}$, and $\mathrm{Cr}$ have been shown to be below maximum permitted values, except $\mathrm{Cr}$, which was slightly higher than the World Health Organisation proposed limit (Saggu et al., 2006).

Although many herbs are well known and applied in a traditional medicine for a very long time, even up to $80 \%$ of the population in the developing countries (Saggu et al., 2007), there are still insufficient reports about their safety and possible toxicity and/or carcinogenicity. Sea buckthorn vegetative parts are not an exception, and thus there also is a need for more safety and toxicity tests on extracts prepared using different solvents, their fractions and specific compounds.

\section{THE POSSIBLE APPLICATION OF SEA BUCKTHORN VEGETATIVE PARTS}

The small, yellow to bright red berries of sea buckthorn have been used in food production and medicine for decades in Eurasian countries (Guliyev et al., 2004). They are processed in beverages, jams, and candies, different food supplements, and skin care products (Michel et al., 2012). Meanwhile, other parts of the plant, such as leaves, bark, roots, stems, mainly are used in folk medicine. Leaves were used as a fodder in ancient times, but presently for tea beverages and lately for the production of pharmaceuticals, food supplements, and cosmetics (Arimboor et al., 2008; Chauhana et al., 2008; Lee et al., 2011).

Leaves of this plant, due to the high concentrations of valuable compounds, have gained increasing interest among scientists. However, during berry processing they are considered as an agricultural waste. Shunguang et al. in 2003 reported that sea buckthorn leaves and shoots (tender branches) have great potential as a low cost natural biologically active stock material and would be very useful in food processing. Also Kim et al. (2011) in their research on antioxidant and $\alpha$-glucosidase inhibitory activity of the extracts, fractions, and isolated compounds of sea buckthorn leaves concluded that sea buckthorn leaf extracts could be used as natural food compounds. Therefore, the presence of biologi- cally active compounds and antioxidant and antimicrobial properties of extracts of sea buckthorn vegetative parts have potential in the food industry (Kim et al., 2011; Maheshwari et al., 2011).

Sea buckthorn vegetative parts, their extracts or fractions could be used as food components to increase the overall nutritional value of the final product and provide it with functional properties, or as food additives to replace synthetic ones. The antioxidant activity of sea buckthorn parts could be used to prolong shelf-life and quality of food. According to Dzomba et al. (2012) the peroxidation of lipids and oil-based food products is a major concern in the food processing industry. It causes the food quality deterioration and therefore, addition of synthetic oxidation inhibitors to improve stability of lipid products during storage is common practice (Lalas et al., 2011; Dzomba et al., 2012). However, in recent years due to the society awareness of toxicity, possible carcinogenity and adverse effect of commonly used synthetic antioxidants such as butylated hydroxyanisole (BHA) and butylated hydroxytoluene (BHT), the demand for research and application of natural antioxidants derived from plants has increased (Kumar et al., 2011; Michel et al., 2012).

Other challenge for food processors and scientists is an assurance of microbiological quality, which is performed by using elevated temperatures, reduction of water content, nutrient restriction, chilling and freezing, and finally synthetic antimicrobials (Negi, 2012). Although microbial spoilage in foods can be controlled by all these activities, non-desirable changes in nutritional value and sensory attributes can arise.

According to Negi (2012) there is an increasing consumer demand for minimally processed foods and less use of synthetic additives. This has challenged scientists to find the best natural sources of biologically active substances, improve their extraction and processing techniques, and develop their application methods.

Therefore, various plant extracts from leaves, seeds and spices have been explored in order to find and develop not only additives with functional and health promoting properties, but also alternatives to synthetic antioxidants and antimicrobials to inhibit food borne pathogens and lipid oxidation processes, which could ensure the safety of products and extend their shelf life (Hossain et al., 2010; Perumalla and Hettiarachchy, 2011).

Lipid oxidation, which leads to decrease of quality of oil and other lipid-rich products quality, can be reduced by adding different plant extracts for quality preservation. Oxidative stability of product with regard to added antioxidants has been reported by many authors. For example, sunflower, palm and olive oils enriched with olive leaf extract containing $200 \mathrm{mg} / \mathrm{kg}$ polyphenols to oils was tested for antioxidant capacity and oxidative stability, in comparison with those enriched with commercial additives, using the 1,1-diphenyl-2-picrylhydrazyl (DPPH) radical scavenging activity test and the Rancimat method, respectively (Salta et 
$a l .$, 2007). Both antioxidant capacity and oxidative stability significantly were higher after enrichment with the extracts, likely due to presence of phenolics like oleuropein, hydroxytyrosol, and quercetin.

The effect of methanol extracts of sage, oregano and rosemary on butter stability during storage was evaluated by Ayar et al. (2001). The extracts were added to butter at concentrations of 0.02 and $0.05 \%$, also $0.02 \%$ BHA, and untreated controls were prepared, and stored at 25 or $5{ }^{\circ} \mathrm{C}$ temperature. Peroxide, free fatty acids and thiobarbituric acid level were monitored during storage. The extracts of spices significantly stabilised the butter against oxidation, showing even better results than the commonly used synthetic antioxidant BHA. The sage extract proved to be the most effective.

Together with the prevention of lipid oxidation, also antimicrobial activity of leaf extracts on the food products has been observed (Gök and Bor, 2012). In this study, the effect of methanolic olive leaf extract (500 and 1000 ppm) on colour, lipid oxidation, microbiological and sensory quality of meatballs during ten-day storage were evaluated. The shelf-life of raw meatballs stored at $4{ }^{\circ} \mathrm{C}$ is around seven days, and the main reason for spoilage is microorganisms. At the beginning of the experiment, the total aerobic bacteria count of control samples was $4.38 \mathrm{log} \mathrm{cfu} / \mathrm{g}$, after ten days of storage it even exceeded the maximal allowance of meat and meat products $(7.0 \mathrm{log} \mathrm{cfu} / \mathrm{g})$ and reached 8.09 $\log \mathrm{cfu} / \mathrm{g}$. However, samples treated with olive leaf extract at concentrations of 500 and 1000 ppm showed only 6.53 and $6.34 \log \mathrm{cfu} / \mathrm{g}$, respectively. Also the level of psychrophilic, Pseudomonas, lactic acid, Enterobacteriaceae, yeasts and mould microbiological counts after storage were lower in meatballs with olive leaf extract than in those of the control. Therefore, the authors suggested the leaf extract as an effective natural antioxidant and antimicrobial agent to improve overall quality and extend the shelf-life of meatballs.

Plant extracts also can be used as antimicrobial agents instead of traditionally used sanitising agents, for example, green tea extract instead of chlorine solution for lettuce washing (Barry-Ryan et al., 2008). During the preparation of food products, often valuable compounds are lost, and therefore, enrichment with extracts would be a good method to increase the nutritional value of the final product. This was shown in a study by Lalas et al. (2011), in which table olives were immersed in $10 \%$ olive leaf water extract for one week, which increased phenolic like oleuropein and hydroxytyrosol concentrations by 400 and 100 times, respectively. The authors suggested that the low-cost stock material, minimal energy consumption and simple extraction procedure used in the present study, would not make a significant increase in the costs of production, and further, that use of olive leaf water extracts should be considered in food processing.

According to the literature, the influence of some plant extracts, mainly olive leaves, green tea, seed, and spices, have been much studied, while the experiments of sea buckthorn leaves and other vegetative parts have focused on chemical compounds and their provided activities.

The diverse biochemical content of sea buckthorn vegetative parts suggests that their processing is undervalued, and their application in food, pharmacological, and cosmetic industries should be explored and developed more intensively.

\section{CONCLUSIONS}

Great variation of lipophilic and hydrophilic compounds is found in the composition of different vegetative parts of sea buckthorn plant. It is believed that they provide antioxidant, antibacterial and antifungal activity, together with antiinflammatory, cytoprotective and antivisceral obesity activity of this plant. Therefore, extracts of sea buckthorn vegetative parts should be considered for use not only in cosmetics and pharmacy, but also in the food industry.

Hence, more knowledge should be acquired about specific compounds, their changes under different conditions, interactions between them and other constituents, their activity in the human body and their impact on health.

\section{ACKNOWLEDGEMENTS}

Research and publication was done in framework of ERDF project "Use of sea buckthorn vegetative parts for development of food products with high antioxidant activity" (2010/ 0246/ 2DP2.1.1.0/ 10/ APIA/ VIAA/ 159).

\section{REFERENCES}

Arimboor, R., Kumar, K.S., Arumughan, C. (2008). Simultaneous estimation of phenolic acids in sea buckthorn (Hippophae rhamnoides) using RP-HPLC with DAD. J. Pharm. Biomed. Anal., 47, 31-38.

Arora, R., Mundra, S., Yadav, A., Srivastava, R. B., Stobdan, T. (2012). Antimicrobial activity of seed, pomace and leaf extracts of sea buckthorn (Hippophae rhamnoides L.) against foodborne and food spoilage pathogens. Afr. J. Biotechnol., 11 (45), 10424-10430.

Ayar, A., Özcan, M., Akgül, A., Akin, N. (2001). Butter stability as affected by extracts of sage, rosemary and oregano. J. Food Lipids, 8 (1), 15-25.

Barry-Ryan, C., Martin-Diana, A., Rico, D. (2008). Green tea extract as a natural antioxidant to extend the shelf-life of fresh-cut lettuce. Innov. Food Sci. Emerg. Technol., 9, 593-603.

Bekker, N. P., Glushenkova, A. I. (2001). Components of certain species of the Elagnaceae family. Chem. Nat. Comp., 37 (2), 97-116.

Bekker, N. P., Glushenkova, A. I. (2006). Lipids of sea buckthorn (Hippophae rhamnoides L.) leaves. In: Singh, V. (Ed.). Seabuckthorn (Hippophae L.): A Multipurpose Wonder Plant. Vol. II: Biochemistry and Pharmacology (pp. 228-238). Delhi: Daya Publishing House.

Chauhana, A. S., Negi, P. S., Ramteke, R. S. (2008). Antioxidant and antibacterial properties of sea buckthorn (Hippophae rhamnoides L.). In: Singh, V. (Ed.). Seabuckthorn (Hippophae L.): A Multipurpose Wonder Plant., Vol. III: Advances in Research and Development (pp. 374-396). Delhi: Daya Publishing House.

Dudonne, S., Vitrac, X., Coutiere, P., Woillez, M., Merillon, J. M. (2009). Comparative study of antioxidant properties and total phenolic content of 
30 plant extracts of industrial interest using DPPH, ABTS, FRAP, SOD, and ORAC assays. J. Agr. Food Chem., 57, 1768-1774.

Dzomba, P., Togarepi, E., Musekiwa, C., Chagwiza, C. J. (2012). Improving oxidative stability of soya and sunflower oil using Temnocalyx obovatus extracts. Afr. J. Biotechnol., 11 (50), 11099-11103.

Escribano-Bailon, M. T., Santos-Buelga, C. (2003). Chapter 1: Polyphenols Extraction from Foods. In: Santos-Buelga, C. and Williamson, G. (eds.). Methods in Polyphenol Analysis (pp. 1-16). Cambridge, UK: Royal Society of Chemistry.

Ganju, L., Padwad, Y., Singh, R., Karan, D., Chanda, S., Chopra, M. K., Bhatnagar, P., Kashyap, R., Sawhney, R. C. (2005). Anti-inflammatory activity of Seabuckthorn (Hippophae rhamnoides) leaves. Int. Immunopharm., 5 (12), 1675-1684.

Geetha, S., Ram, M. S., Singh, V., Ilavazhagan, G., Sawhney, R. C. (2002). Effect of seabuckthorn on sodium nitroprusside-induced cytotoxicity in murine macrophages. Biomed. Pharmacother., 56 (9), 463-467.

Geetha, S., Sai Ram, M., Mongia, S.S., Singh, V., Ilavazhagan, G., Sawhney, R. C. (2003). Evaluation of antioxidant activity of leaf extract of Seabuckthorn (Hippophae rhamnoides L.) on chromium (VI) induced oxidative stress in albino rats. J. Ethnopharm., 87 (2-3), 247-25.

Goldberg, E. D., Amosova, E. N., Zueva, E. P., Razma, T. G., Krylova, E. G., Reikhart, D. V. (2004). Effects of extracts from medicinal plants on the development of metastatic process. Bull. Exper. Biol. Med., 138 (3), 288-294.

Gök, V., Bor, Y. (2012). Effect of olive leaf, blueberry and Zizyphus jujuba extracts on the quality and shelf life of meatball during storage. J. Food Agr. Environ., 10 (2), 190-195.

Guliyev, V. B., Gul, M., Yildirim, A. (2004). Hippophae rhamnoides L.: chromatographic methods to determine chemical composition, use in traditional medicine and pharmacological effects. J. Chromatogr., B, 812, 291-307.

Harshit, V., Rajesh, C., Akansha, P., Mandeep, S. (2011). Antibacterial properties of seabuckthorn (Hippophae rhamnoides L.) leaf extracts against common skin and wound bacteria. Ind. J. Vet. Res., 20 (1), 38-41.

Hossain, M. B., Barry-Ryan, C., Martin-Diana, A. B., Brunton, N. P. (2010). Effect of drying method on the antioxidant capacity of six Lamiaceae herbs. Food Chem., 123, 85-91.

Hua, L. X., Zhang, L. H. (2008). Biochemical changes in flavonoids during ripening of seabuckthorn berries and leaves. In: Singh, V. (Ed.). Seabuckthorn (Hippophae L.): A Multipurpose Wonder Plant. Vol. III. Advances in Research and Development (pp. 228-242). Delhi: Daya Publishing House.

Jain, M., Ganju, L., Katiyal, A., Padwad, Y., Mishra, K. P., Chanda, S., Karan, D., Yogendra, K. M. S., Sawhney, R. C. (2008). Effect of Hippophae rhamnoides leaf extract against Dengue virus infection in human blood-derived macrophages. Phytomedicine, 15, 793-799.

Jeong, H. J., Ji Won Lee, J. W., Kim, K. S., Kim, J. S., Han, S. N., Yu, C. Y., Lee, K. J, Kwon, S. Y., Kim, J. M. (2010). Antioxidant and antimicrobial activities of extracts from a medicinal plant, sea buckthorn. J. Korean Soc. Appl. Biol. Chem., 53 (1), 33-38.

Kalia, K. R., Singh, R., Rai, K. M. Mishra, G. P., Singh, S. R. (2011). Review: Biotechnological interventions in sea buckthorn (Hippophae L.): Current status and future prospects. Trees Struct. Funct., 25 (4), 559-575.

Kim, J. S., Kwon, Y. S., Sa, Y. J., Kim, M. J. (2011). Isolation and identification of sea buckthorn (Hippophae rhamnoides) phenolics with antioxidant activity and $\alpha$-glucosidase inhibitory effect. J. Agr. Food Chem., 59 (1), $138-144$.

Kondakova, V., Tsvetkov, I., Batchvarova, R., Badjakov, I., Dzhambazova, T., Slavov, S. (2009). Review. Phenol compounds - qualitative index in small fruits. Biotechnol. Biotechnol. Equip., 23, 1444-1448.

Kumar, K. S., Ranjith, A., Sreevidya, S. D., Arumughan, C. (2008). Antioxidant and DNA protective activities of sequential extracts of sea buckthorn (Hippophae rhamnoides L.) leaves. In: Singh, V. (Ed.). Seabuckthorn
(Hippophae L.): A Multipurpose Wonder Plant. Vol.III. Advances in Research and Development (pp. 371-373). Delhi: Daya Publishing House.

Kumar, Y. M. S., Dutta, R., Prasad, D., Misra, K. (2011). Subcritical water extraction of antioxidant compounds from sea buckthorn (Hippophae rhamnoides) leaves for the comparative evaluation of antioxidant activity. Food Chem., 127, 1309-1316.

Lalas, S., Athanasiadis, V., Gortzi, O., Bounitsi, M., Giovanoudis, I., Tsaknis, J., Bogiatzis, F. (2011). Enrichment of table olives with polyphenols extracted from olive leaves. Food Chem., 127 (4), 1521-1525.

Lee, H. I., Kim, M. S., Park, S. K., Seo, K. I., Kim, H. J., Kim, M. J., Choi, M. S., Lee, M. K. (2011). Anti-visceral obesity and antioxidant effects of powdered sea buckthorn (Hippophae rhamnoides L.) leaf tea in diet-induced obese mice. Food Chem. Toxicol., 49 (9), 2370-2376.

Li, T. S. C., Wardle, D. (2003). Effect of harvest period on the protein content in sea buckthorn leaves. Can. J. Plant Sci., 83 (2), 409-410.

Maheshwari, D. T., Kumar, Y. Y. S., Verma, S. K., Singh, V. K., Singh, S. N (2011). Antioxidant and hepatoprotective activities of phenolic rich fraction of Seabuckthorn (Hippophae rhamnoides L.) leaves. Food Chem. Toxicol., 49 (9), 2422-2428.

Michel, T., Destandau, E., Le Floch, G., Lucchesi, M. E., Elfakir, C. (2012) Antimicrobial, antioxidant and phytochemical investigations of sea buckthorn (Hippophae rhamnoides L.) leaf, stem, root and seed. Food Chem., 131, 754-760.

Narayanan, S., Ruma, D., Gitika, B., Sharma, S. K., Pauline, T., Sai Ram, N., Ilazahagan, G., Sawhney, R. C., Kumar, D., Banerjee, P. K. (2005). Antioxidant activities of seabuckthorn (Hippophae rhamnoides) during hypoxia induced oxidative stress in glial cells. Mol. Cell. Biochem., 278 (1-2), 9-14.

Negi, P. S. (2012). Review: Plant extracts for the control of bacterial growth: Efficacy, stability and safety issues for food application. Int. J. Food Microbiol., 156, 7-17.

Padwad, Y., Ganju, L., Jain, M., Chanda, S., Karan, D., Banerjee, K. P., Sawhney, C. R. (2006). Effect of leaf extract of Sea buckthorn on lipopolysaccharide induced inflammatory response in murine macrophages. Int. Immunopharm., 6, 46-52.

Perumalla, A. V. S., Hettiarachchy, N. S. (2011). Review: Green tea and grape seed extracts - Potential applications in food safety and quality. Food Res. Int., 44, 827-839.

Popescu, M., Dune, A., Ivopol, G., Ionescu, D. (2010). Powders and extracts of plants as an interesting source of bioavailable minerals. A focus upon the mineral content of certain agricultural soils. In: Proceeding of the International Conference on New Research in Food and Tourism - BIOATLAS 2010, 28-30 May 2010 (pp. 96-99). Transilvania University of Brasov, Romania.

Poiana, M. A. (2012). Enhancing oxidative stability of sunflower oil during convective and microwave heating using grape seed extract. Int. J. Mol. Sci., 13 (7), 9240-9259.

Prabhu, R. A., Prasad, G. A., Manivannan, J., Elavarasan, S., Balaji, S. (2011). Review on currative assets of seabuckthorn. J. Pharm. Res., 4 (1), $164-166$.

Saggu, S., Diverkar, H. M., Gupta, V., Sawhney, R. C., Banerjee, P. K., Kumar, R. (2007). Adaptogenic and safety evaluation of seabuckthorn (Hippophae rhamnoides) leaf extract: A dose dependent study. Food Chem. Toxicol., 45 (4), 609-617.

Saggu, S., Gupta, V., Sawhney, R. C., Rai, P. K., Kumar, R. (2006). Analysis of heavy metals in herbal extracts of high altitude growing plants Hippophae rhamnoides and Rhodiola imbricate. Toxicol. Int., 13 (2), 111-117.

Saggu, S., Kumar, R. (2007). Possible mechanism of adaptogenic activity of seabuckthorn (Hippophae rhamnoides) during exposure to cold, hypoxia and restraint (C-H-R) stress induced hypothermia and post stress recovery in rats. Food Chem. Toxicol., 45 (12), 2426-2433. 
Saggu, S., Kumar, R. (2008). Effect of seabuckthorn leaf extracts on circulating energy fuels, lipid peroxidation and antioxidant parameters in rats during exposure to cold, hypoxia and restraint $(\mathrm{C}-\mathrm{H}-\mathrm{R})$ stress and post stress recovery. Phytomedicine, 15 (6-7), 437-446.

Salta, F. N., Mylona, A., Chiou, A., Boskou, G., Andrikopoulos, N. K. (2007). Oxidative stability of edible vegetable oils enriched in polyphenols with olive leaf extract. Food Sci. Technol. Int., 13 (6), 413-421.

Sanchez de Medina, V., Priego-Capote, F., Jimenez-Ot, J., Luque de Castro, M. D. (2011). Quality and stability of edible oils enriched with hydrophilic antioxidants from the olive tree: The role of enrichment extracts and lipid composition. J. Agr. Food Chem., 59, 11432-11441.

Shahidi, F., Naczk, M. (2004). 8 Antioxidant properties of food phenolics. In: Shahidi, F., Naczk, M. (eds.). Phenolics in Food and Nutraceuticals (pp. 403-442). USA, FL: CRC Press, Boca Raton.

Shunguang, L., Zhengping, J., Xiufeng W., Keqin W., Dengming L. (2003). Sea buckthorn breeding for the purpose of leaves utilization. In: Proceed- ings of the $1^{\text {st }}$ Congress of the International Seabuckthorn Association, 14-18 September 2003 (pp. 36-46). Berlin.

Upadhyay, N., Gupta, A. (2010). In vitro and dermal toxicity studies for Hippophae rhamnoides L. leaf extract. Toxicol. Lett., 196S, S249.

Upadhyay, N. K., Kumar, M. S. Y., Gupta, A. (2010). Antioxidant, cytoprotective and antibacterial effects of Sea buckthorn (Hippophae rhamnoides L.) leaves. Food Chem. Toxicol., 48, 3443-3448.

Xu, Y. J., Kaur, M., Dhillon, R. S., Tappia, S. P., Dhalla, N. S. (2011). Health benefits of sea buckthorn for the prevention of cardiovascular diseases. $J$. Funct. Foods, 3, 2-12.

Xu, X., Xie, B., Pan, S., Liu, L., Wang, Y., Chen, C. (2007). Effects of sea buckthorn procyanidins on healing of acetic acid-induced lesions in the rat stomach. Asia Pac. J. Clin. Nutr., 16 (1), 234-238.

Zu, Y., Li, C., Fu, Y., Zhao, C. (2006). Simultaneous determination of catechin, rutin, quercetin kaempferol and isorhamnetin in the extract of sea buckthorn (Hippophae rhamnoides L.) leaves by RP-HPLC with DAD. J. Pharm. Biomed. Anal., 41 (3), 714-719.

7 December 2012

\section{SMILTSĒRKŠĶU VEĢETATĪVĀS DAL̨AS — NOZĪMĪGS BIOLOG̦ISKI AKTĪVO SAVIENOJUMU AVOTS}

Pēdējos gados ir palielinājusies patēēetāju interese par veselīgiem, minimāli apstrādātiem produktiem, kas nesatur pārtikas piedevas. Līdz ar to tiek meklēti dabiski avoti dažādu bioloğisko savienojumu iegūšanai, tādēl palielinās pētījumu skaits, piemēram, par olīvu lapām vai zalıajām tējām un to ekstraktu pielietojumu. Smiltsērkšķis ir labi zināms kā l̦oti vērtīgs augs, kuram ne tikai ogas, bet arī citas auga dal̦as, kuras jau sen tiek izmatotas dažādu tautu tradicionālajā medicīnā, satur daudz nozīmīgu savienojumu. Tām ir potenciāls ne tikai farmācijā un kosmētikas ražošanā, bet arī pārtikas pārstrādes procesos kā sintētisko piedevu aizstājējam vai produktu funkcionālo īpašỉbu papildinātājam. Rakstā tiek sniegta literatūras analīze par informāciju, pieredzi un pamatojumu, kāpēc smiltsērkšķu veǵetatīvās daḷas ir nozīmīgas un vērtīgas turpmākai izpētei. Daudzi autori smiltsērkšḳu veğetatīvās daḷas raksturo kā bagātas ar fenolsavienojumiem, karotinoīdiem, tokoferoliem, vitamīniem un minerālvielām, taču joprojām trūkst pētījumu par konkrētiem savienojumiem un to saturu, turklāt liela dạ̣a datu ir novecojuši, jo iegūti 20. gadsimta 60.-80. gados. Smiltsērkšḳu veǵetatīvo daḷu ekstraktiem, saskaṇā ar literatūru, ir novērota daudzveidīga aktivitāte, piemēram, antioksidatīvā un antibakteriālā, tāpat arī pretiekaisuma, pretaptaukošanās, pretradiācijas, šūnu aizsargājošā u.c., savukārt ietekme uz cilvēka veselību, drošības un toksiskuma testi ir maz pētīit. Apkopojot pieejamo literatūru, var secināt, ka smiltsērkšḳu lapām tiek pievērsta pastiprināta uzmanība un pētījumu skaits aug, kamēr citas auga veǵetatīvās daḷas kā zari, saknes, jaunie dzinumi ir aizmirsti. 